\title{
Study of Internet Financing to Small and Micro Businesses
}

\author{
Xiangxiao Gao \\ Great Wall College \\ China University of Geosciences \\ Baoding, China
}

\begin{abstract}
Firstly, this article introduced the correlation theory of Small \& Micro Businesses and Internet Financing; it also introduced the two main modes of how to use internet financing for Small \&Micro Businesses. Secondly, through the investigation to current situation of internet financing of Small \&Micro Businesses, this article make a summarize to the problems which happened in the process of internet financing to Small \&Micro Businesses. At last, according to current economic and legal environment, this article raised the measures about how to accelerate the internet financing of Small \&Micro Businesses.
\end{abstract}

Keywords-Small \&Micro Businesses; internet financing; P2P; Crowdfunding

\section{INTRODUCTION OF CORRELATION THEORY}

\section{A. The Features of Small \&Micro Businesses}

$18^{\text {th }}$ June, 2011, "The Classification Standards of Small $\&$ Micro Businesses" were launched by Ministry of Industry and Information Technology (MIIT)、 National Bureau of Statistics (NBS) 、 National Development and Reform Commission (NDRC)、Ministry of Finance, this Standard provide detail classify rules to Small \& Micro Businesses. The old classification standards were abandoned. According to the new Classification Standards, there are following features to Small \& Micro Businesses: first, there is a big sum of Small \& Micro Businesses, involved lots of industry and districts, it occupied more than $95 \%$ of our total enterprises and located in different district of China; secondly, most of Small \& Micro Businesses are in a bad financial situation, this is the primary factor which constrained the development of Small \& Micro Businesses; thirdly, poor risk resistance ability, because of the limitation of operating scale, etc., it is easy to bankrupt, close down when the market supply-demand balance were changed.

\section{B. Internet Financing and Its Development Process}

Internet Financing is the new financing mode which combined the internet technology and corporate financing.
The China Merchants Bank have launched the Online Banking to do the banking business by the end of 1990's. After that, the other banks also launched similar online banking services. With the development of internet technology, the online banking services are more and more used to do the receipt and payment of their capital. On 13rd, June, 2013, the "Yuebao" was launched by Alibaba and Tianhong Asset Management Co., Ltd; it is accepted by most of users because of its fast and convenience, and it is spread fast in China. Its net value reached to RMB613.38 billion by June 2015. This new financing mode attracts the investor and financers' favor. There are many internet financing tools come to the market which similar to Yuebao, it become a new financing mode in China following with some other financing mode, such as "Third-Party Payment", "P2P", "Crowdfunding", "Virtual Money", "Internet Insurance", etc. Especially "P2P" and "Crowdfunding" which open up a new financing method to Small \& Micro Businesses. The development of Internet finance bring a great impact to our economic environment, and it is stimulate the improvement of finance market.

\section{Main Internet Financing Mode}

\section{1) P2P Internet loan}

$\mathrm{P} 2 \mathrm{P}$ is the abbreviation of "peer to peer", it means person to person. $\mathrm{P} 2 \mathrm{P}$ internet loan means to connect the private fund demander and private fund provider by using internet platform, to realize the financing demand of fund demander and investment demand of fund provider. "ppdai" founded in 2007 which is the earliest P2P internet loan platform, this new internet loan mode were accepted by more and more people accompanying with more and more similar platforms were launched, see Chart 1 . There are 2520 P2P platforms by the end of Oct, 2015. Compare to the statistic data of Jan 2015 and Oct 2015, there is a big increase of investor and borrower, it is 33.34times of Oct turnover compare to Jan which certify the P2P internet loan mode are rapidly spread out in China. 
TABLE I. Chart 1 P2P OPERATING StATE OF JAN, OCT 2015

\begin{tabular}{|c|c|c|c|c|c|c|c|}
\hline Month & $\begin{array}{c}\text { Turnover } \\
\text { (Billion Rmb) }\end{array}$ & $\begin{array}{c}\text { No. of } \\
\text { Platforms }\end{array}$ & $\begin{array}{l}\text { Loan Balance } \\
\text { (Billion Rmb) }\end{array}$ & $\begin{array}{c}\text { Average Loan } \\
\text { Time }\end{array}$ & $\begin{array}{l}\text { Investors } \\
\text { (Million) }\end{array}$ & $\begin{array}{c}\text { Borrowers } \\
\text { (Million) }\end{array}$ & $\begin{array}{l}\text { Comprehensive } \\
\text { Interest Rate }\end{array}$ \\
\hline Oct & 119.65 & 2520 & 351.55 & 6.78 months & 2.4734 & 0.581 & $12.38 \%$ \\
\hline Jan & 35.78 & 1627 & 112.06 & 6.87 months & 0.8822 & 0.191 & $15.81 \%$ \\
\hline
\end{tabular}

\section{2) Crowdfunding Mode}

Crowdfunding come from abroad, means financing from multitude. The public will invest according to their own invest willing after the organizer launch the project investment. This financing mode come to China in 2011, "demohour" is the first crowdfunding website in China which founded at July 2011. Crowdfunding include many ways, such as handout, reward, bond, shareholding, etc. According to the statistic data from TRJCN.COM, by the end of 31st, Oct, 2015, there are 296 crowdfunding platforms are under operating, $89 \%$ of the crowdfunding are using shareholding method. The fund demander will provide a very attractive ROI to the investors, which is huge attractive to the investors, so that the growth rate of financing is increasing continuously.

\section{The Advantages of Internet Financing Mode to Small \& Micro Businesses}

Difficulty of financing is always the main problem which restraint the development of Small \& Micro Businesses, the Internet financing is a new way to overcome such problems. Compare to traditional loan mode, internet financing is more fast and convenient, the success rate is also higher than traditional loan mode. Compare to loan cost, the internet financing saved a lot of extra cost and reduced some unnecessary approval processes. The interest rate is lower for Small \& Micro Businesses if they use internet financing to get fund. And they will have more options to choose the way of paying interest according to their own demands. It is absolutely a good method for Small \& Micro Businesses to solve their financing problems if they can use internet financing mode to get financing in a short time.

\section{The Problems of SMAll \& Micro Businesses DOING INTERNET FINANCING}

\section{A. The Small \& Micro Businesses' Management Level is Limited and Moral Risks Are Easily to Happen}

At present, the credit risks are frequently happened among the Small \& Micro Businesses because of itself poor operational strength, etc. At first, regards to the business management, most of the Small \& Micro Businesses are lack of mature operational and management experience. It has flexibility during daily operational and management, but because of the management level is not enough, it was fallen behind in the operating decision aspect, and it can't rightly response with the fluctuation of economic and finance environment; some of them even have the risks of running out of cash. Secondly, the Small \& Micro Businesses are easily to have moral risks and adverse selection. The funding will have specific purpose according to the financing contract, but what the Small \& Micro Businesses are actually done is to use the fund for other purposes or nonbusiness purpose frequently. That huge increased the take back risks of such funding. All these situations will lead the Small \& Micro Businesses to the insolvent condition, thus credit risks will come. The credit risks of such Small \& Micro Businesses will make the investors face a huge risk, caused the investors give up investment to such Businesses.

\section{B. Internet Security Risks of Internet Financing}

Along with the internet going into human lives gradually and it has penetrated to each corner of human lives very fast. Internet Financing is also benefit from the internet high speed development, and become a new financing mode which brings benefits to Small \& Micro Businesses; it is accelerate the emergence and growth of the new generation Small \& Micro Businesses. But internet itself has the security risks which is the big challenge to Small \& Micro Businesses and the financing platforms.

TABLE II. INFORMATION SAFETy GROUP Division OF CHINESE NETIZEN

\begin{tabular}{|c|l|l|l|c|}
\hline $\begin{array}{c}\text { Group } \\
\text { Division }\end{array}$ & $\begin{array}{c}\text { Safety } \\
\text { Group }\end{array}$ & $\begin{array}{c}\text { Risky } \\
\text { Group }\end{array}$ & $\begin{array}{c}\text { Mild } \\
\text { Affected } \\
\text { Group }\end{array}$ & $\begin{array}{c}\text { Heavy } \\
\text { Affected } \\
\text { Group }\end{array}$ \\
\hline Percentage & $25.9 \%$ & $29.6 \%$ & $28.3 \%$ & $16.2 \%$ \\
\hline
\end{tabular}

According to the data from Chart II, the affected netizen occupy $44.5 \%$ among all of the netizen, risky group occupy $29.6 \%$, the safety group just occupy $25.9 \%$. As you can see, at present we live in the internet era, the internet security are continuous threat to all the netizen. The threats includes: rogue program, fake website, fraud website, and other frauds from internet, it seriously affected the smooth development of internet financing for Small \& Micro Businesses. On one hand, it is a huge cost to build an internet defense system for internet financing platform, and it will increase the cost of internet financing; on the other hand, it is very easy to disclose the Enterprises information and cause bad affect to the Small \& Micro Businesses.

\section{Lack of Right Supervision Mechanism, Laws and Regulations}

At first, Internet Financing is private lending based on the mutual benefit and win-win result of both parties, it is a new financing mode which protected by laws. It attract big sum of private funds to internet financing, and become an "Inclusive Financial" which suitable for Small \& Micro Businesses to meet their financial demands. It exposed many problems during the Internet Financing executing process, which tells us to improve the supervision mechanism of Internet Financing. According to the statistic data from Wangdaizhijia, there are 2520 platforms by the end of Oct 2015, among them 1078 platforms have problems. The main 
problems are run away with the fund, close down, difficult to withdraw the deposit, etc. It will make the investors bear loss if the internet financing have problems, and it will make bad influence to the continuous promote of Internet Financing. All these are result from the lack of supervision and law restriction mechanism of the Internet Financing. At present, the "Contract Law" and "Credit Rule" are the main laws the internet financing subject to. But there is not clear criterion to the permission, operating, capital withdrawal of Internet Financing. And it is also not clear about which department to do the supervision of the platform. Especially to the Small \& Micro Businesses, the moral risks are very high, the main reasons result to Internet Financing problems are abuse the fund, the absence of supervision mechanism.

\section{Irregular Credit System of Internet Financing}

It is necessary to do more credit study of Small \& Micro Businesses when they apply for Internet Financing, because of the low operating management ability which make the operating risks are easy to happen. Currently the credit study are mainly from the internet data, the credit analyze of borrower are based on their information record, it saved the third party checking process. But it is easy for borrowers to make some fake information by this way, which will make the credit evaluation to be meaningless. Furthermore, the authenticity of credit evaluation will increase a lot by information sharing from different internet financing platforms and financing institution, and the credit evaluation cost will drop a lot, so that the credit evaluation efficiency will increase a lot.

\section{ThE MEASURES TO PROMOTE INTERNET FINANCING OF SMALL \& MICRO BUSINESSES}

\section{A. Improve the Credit Evaluation System Construction of Small \& Micro Businesses}

The Small \& Micro Businesses has the features of instability and high risks when operation. Before provide internet financing, the strictly credit evaluation to Small \& Micro Businesses will increase the stability of internet financing. "Credit Regulations" build the basic framework to the financing credit evaluation, but it is lack of the regulations about how to make it. At present, the internet financing platforms are checking the borrower's credit through the internet data, it is can't avoid the fake internet information. To drop the untruthful rate of enterprises credit caused by fake internet information, it needs the cooperation of internet financing platforms and financing institutions to share the enterprises information. Furthermore, try to increase the punishment if find enterprises provide fake information, so that to protection the right or fund providers and promote the smooth development of internet financing.

\section{B. Improve the Construction of Internet}

The internet have entered into every corner of human lives with a lot of convenience, we also face the risks from Internet. And the internet financing also facing the threats comes from security risks of the internet. Try to avoid such threats, the website need to use very strong technology to against the hackers, against the internet steal; secondly, the internet risks also come from the processing programs, how to prevent internet risks should be considered when these processing programs were designed; thirdly, the punishment measures should be list in the national laws.

\section{Improve the Specialized Laws and Regulations}

Perfect laws and regulations are the safeguard to carry out internet financial smoothly, the lack of such laws and regulations are the main problems need to be solved at moment. On one hand, it lead to the internet financial supervision no laws to apply, make the supervision system to disorder; on the other hand, current laws and regulations are lack of the privacy protection to the parties who join the internet financing, which lead to the loss by information disclosure. It includes following aspects to do the construction of laws and regulations:

First, improve the laws of internet financing admittance. Register in the internet financing platform is the first step to join the internet financing, make a strictly control to the admittance qualification of internet financiers, it is helpful to improve the quality of internet financing participants, and establish a good basis for the following works.

Second, found the information protection regulations of internet financing participants. According to the credit investigation and through the integration and analyze of the data, to get a more precise information, that is the core confidential of business operating, which will make a big loss if it is disclosed. Stand on the angle of financing corporate, the law should consider protecting the privacy.

Third, explicit the supervision duty of each supervision department. There are many supervision department because of the internet finance relate to many industries, it is helpful to realize the effective supervision of internet financial. It will good to the further development of internet financial if the supervision duty can be clear define in the laws.

\section{Improve the Supervision System of Internet Financing}

Currently speaking, the internet financing mainly includes: third-party payment, P2P, Crowdfunding, virtual currency, etc. It make the internet finance supervision includes banks supervision, securities regulation, internet supervision, etc. So the first thing to improve the supervision system is to clear define the supervision duty of each supervision department. On the other hand, there should have clear supervision system to each phase of internet financing, especially for the moral risks which are easily happen among Small \& Micro Businesses. There should be have strictly admittance qualification supervision to the enterprises and private who join the internet financing, the supervision department are also need to do the tracking in the process of fund operating. At last, the supervision measures are also necessary when the investors withdraw the fund, to protect the investors profits, it is needed to make an objective evaluation to the project profit or loss. By this way, the whole supervision system is built, include beforehand, inwards and afterwards supervision, such there part is an entirety. 


\section{REFERENCES}

[1] Zhu Rui, The Study of risk prevention about P2P internet loan platform[D], AnHui Uniersity, 2014(4)

[2] Tan Jiaxin, The study of financing problems in HuNan villages and towns Small \& Medium \& Micro businesses [D], Agriculture University of Hu Nan, 2013(11).

[3] Xiao Benhua, The development mode of America crowdfunding financing, and the enlightenment to $\mathrm{China}[\mathrm{J}]$, Southern Finance, 2013(1)

[4] Wu Peng, The method study of internet financial support Small \& Micro Businesses under inclusive finance system[J], College Journal of HeNan University of Technology, 2015(9)

[5] Hong Hao, The supervision and risks of Internet finance[J], Wuhan Finance, 2014(4)

[6] Zheng Zhilai, The method study of Internet Finance, Financal disintermediation and Small \& Micro Businesses financing[J], Southwest Finance, 2015(3) 